\title{
THE RELIABILITY OF THE DETERMINATION OF URINARY PROTEINS BY ELECTROPHORESIS ON FILTER PAPER
}

\author{
BY \\ D. WOLVIUS AND J. C. M. VERSCHURE \\ with the technical assistance of F. C. M. HOEFSMIT \\ From the Medical Department, University Hospital, Utrecht (Netherlands)
}

(RECEIVED FOR PUBLICATION FEBRUARY 15, 1955)

During the last few years several publications have appeared concerning the investigation of urinary proteins by electrophoresis on filter paper (Soulier, 1953; Slater and Kunkel, 1953; Fauvert and Hartmann, 1954). In these a comparative study was made on the basis of the electrophoretic diagrams between the different types of proteinuria and between the serum and urinary proteins in the various diseases accompanied by proteinuria.

The technical simplicity of the filter paper method permits the determination of urinary proteins on a large scale and makes the characterization suitable for clinical purposes.

Diagrams of urinary proteins often show weak protein bands even after sufficient concentration. Moreover, these diagrams often have to be made with a small amount of protein. In these cases, the various disturbing influences of the method may be of relatively greater influence.

\section{Methods}

Concentration of Urine.-The estimation of the urinary protein content is carried out using the sulphosalicylic acid and Esbach methods.

The urines are next concentrated by extracting their crystalloid solution by $15 \%$ aqueous carboxymethylcellulose (C.M.C.).* For this purpose small cellophane bags $\dagger$ are used, which contain about $40 \mathrm{ml}$. of urine. Depending upon the protein content, 20 to $40 \mathrm{ml}$. of urine is concentrated to 2 to $0.2 \mathrm{ml}$. If a high concentration is necessary, fresh C.M.C. may be applied. A 200 -fold concentration can generally be achieved after four or five days. During the process of concentration the urines are kept in the refrigerator at $4^{\circ} \mathrm{C}$.

Instead of C.M.C. a $25 \%$ aqueous solution of polyvinylpyrrolidone may be used, as was suggested by Slater and Kunkel and by Fauvert and Hartmann. The effectiveness of both solutions is about the same; polyvinylpyrrolidone, however, is much more expensive.

* A.K.U. Arnhem, Holland. Factory number XT 843.

† Dialysier schlang. Kalle \& Co., Wiesbaden, Germany.
Electrophoresis.-The tank for electrophoresis described by de Wael (1953) was modified by us for a microtechnique giving good resolutions of the various protein bands within four hours.

In this tank, 36.5 by 43.7 by $37 \mathrm{~cm}$. (Figs. $1 a$ and $1 b$ ), two parallel glass rods (a) are placed $7 \mathrm{~cm}$. above the bottom. The distance between the rods is $10 \mathrm{~cm}$. Two small vessels (b), of which the inner walls (i) are just underneath the glass rods, contain the buffer (barbital buffer, $p \mathrm{H} 8.6$; molar strength $0.1 ; 45.32 \mathrm{~g}$. barbital sodium and $8.08 \mathrm{~g}$. barbital dissolved in $4 \mathrm{l}$. of distilled water). Beside each vessel (b) is another vessel (c), which contains the electrodes (d) and, in addition, buffer. Both vessels (b) and (c) are linked by filter paper (f), damped with buffer. Thus a change of the $p \mathrm{H}$ of the buffer in vessel (b) will be prevented.

The filter paper used is Whatman 1 . Strips, 24 by $4 \mathrm{~cm}$. (h), are suspended over the two glass rods, the ends dipping in the vessels (b). The vertical distance between the surface of the buffer and the horizontal part of the strips must be at least $7 \mathrm{~cm}$., otherwise too much buffer will be absorbed by the strips. Nine strips can be placed beside each other in the tank. So nine sera or urines can be investigated at a time.

After the strips are completely damped with buffer, 0.01 to $0.02 \mathrm{ml}$. of serum or $0.04 \mathrm{ml}$. of concentrated urine is brought on to the horizontal part of the strip in a narrow band parallel to the glass rods, at a distance of $1 \mathrm{~cm}$. from the glass rod on the cathode side. According to the technique of van Os (1952) this is accomplished by means of a polished slide, a little shorter than the width of the strips, the material being evenly distributed along the margin. Fig. 2 shows how this slide is handled.

After the tank has been covered by a glass plate, the current is switched on and the voltage adjusted to $180 \mathrm{v}$. with the help of the two electrodes (g). In view of the shortness of the strips this tension difference is rather high, but the great advantage of this voltage is that within four hours a clear separation between the protein fractions will be obtained.

There appears to be much evaporation in the tank, which is shown by the many droplets of water on the walls. It is caused by the large volume of the tank 

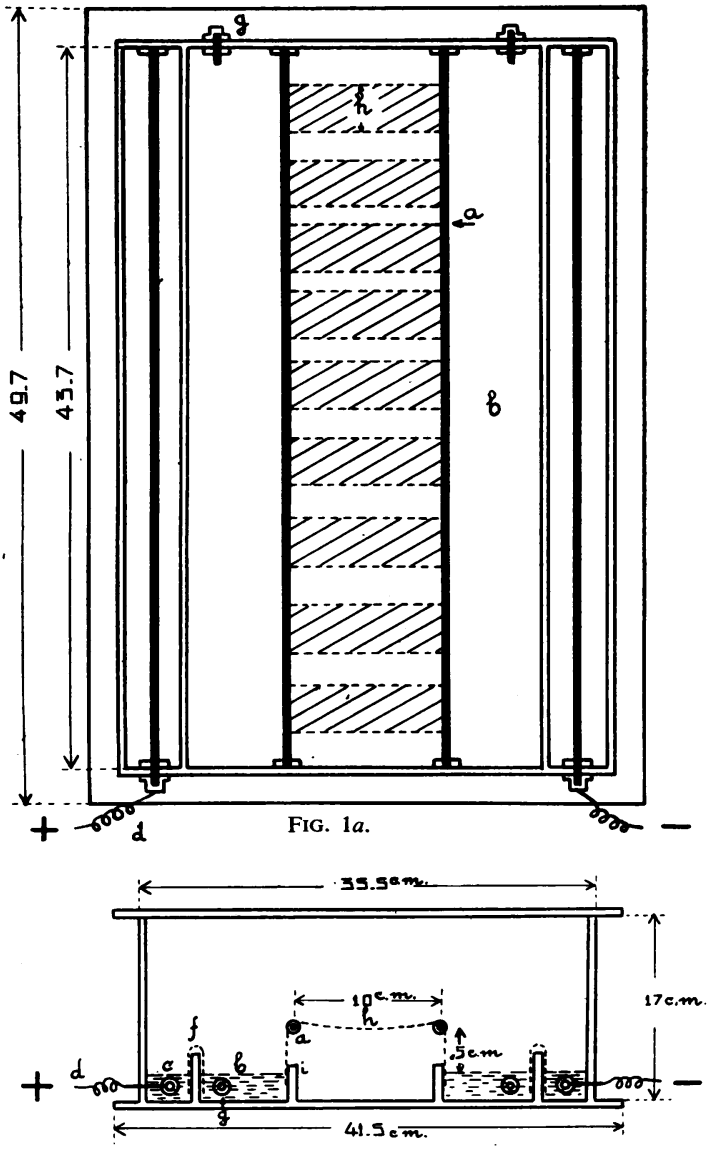

FIG. $1 b$.

FIGs. $1 a$ and $1 b$.-An upper and side view of the tank for electrophoresis (described by de Wael).

and the warming up of the strips by the high-voltage current $\left(2.5^{\circ} \mathrm{C}\right.$. for four hours).

The high tension difference, the evaporation, and probably other factors as well appeared to contribute excellently to obtaining good resolution in very sharp bands. These sharp bands appeared to be of great assistance in the characterization of urinary proteins with very small amounts of proteins.

Fig. 3 is an example of two diagrams made from the urine and the serum of a patient with a nephrosis.
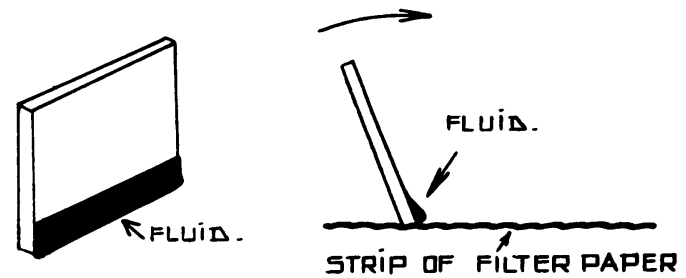

Fig. 2.-The mode of application of the material on the filter paper.

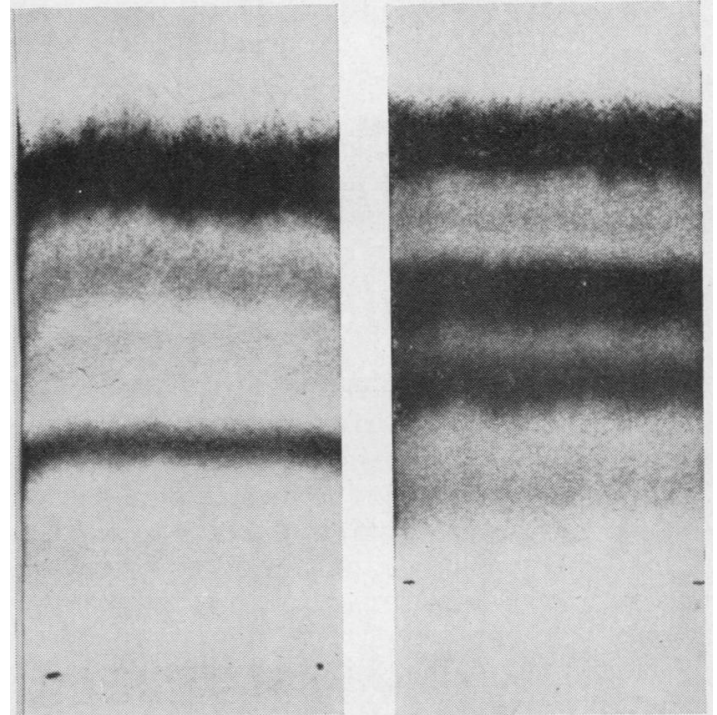

FIG. 3.-Diagrams of urinary and serum proteins of a patient with a nephrosis.

Staining.-After drying the strips for 15 minutes at $110^{\circ} \mathrm{C}$., they are stained in a saturated solution of azocarmine B (Bayer) in methylalcohol, acetic acid, and water $(5: 1: 4)$ for 15 minutes. The strips are next washed three times for five minutes in $10 \%$ acetic acid. After each washing fresh acetic acid is used. The diagrams are dried at room temperature.

The mutual ratio of the protein fractions is determined by cutting out the bands and by extracting them with $5 \mathrm{ml} .1$ in $10 \mathrm{~N}$. NaOH. The extinction of each solution is determined with the Beckmann spectrophotometer.*

The extinctions of the globulin proteins have to be corrected by the factor 1.5 in order to express the mutual ratio of the fractions to their nitrogen content.

TABLE I

FIRST STANDARD DEVIATION OF THE VARIOUS PROTEIN FRACTIONS IN DIFFERENT METHODS OF ESTIMATION

\begin{tabular}{|c|c|c|c|c|}
\hline & Albumin & $\begin{array}{c}\text { Alpha- } \\
\text { globulins }\end{array}$ & $\begin{array}{c}\text { Beta- } \\
\text { globulins }\end{array}$ & $\begin{array}{l}\text { Gamma- } \\
\text { globulins }\end{array}$ \\
\hline $\begin{array}{l}\text { Electrophoresis in free } \\
\text { solution (Dole, 1944) } \\
\text { Electrophoresis in free }\end{array}$ & 2.8 & $\begin{array}{lll}0.7 & 1.3\end{array}$ & 1.9 & 2.5 \\
\hline $\begin{array}{l}\text { Electropnoresis in iree } \\
\text { solution (Ewerbeck, } \\
\text { 1950) .. }\end{array}$ & 2.5 & 1.75 & 0.3 & 1.9 \\
\hline Filter paper electrophor- & $2 \cdot 3$ & 1.0 & 0.8 & 1.4 \\
\hline $\begin{array}{l}\text { Present method of filter } \\
\text { paper electrophoresis }\end{array}$ & 2.4 & 1.0 & 1.4 & 1.48 \\
\hline
\end{tabular}

\section{Reproducibility of the Method for Serum}

This was investigated by determining the standard deviation of the estimation errors for each fraction from 18 analyses of a serum sample performed on

* Franglen and Martin (Biochem. J., 1954, 57, 626) have shown the
impossibility of obtaining absolute values for protein distribution impossibility of obtaining absolute values for protein 
different days. Table I shows the results, together with those of the filter paper method, described by de Wael, and of the method of electrophoresis in free solution determined by Dole (1944) and Ewerbeck (1950). In comparison with these three methods, ours appeared to give even better results.

These standard deviations are only valid for the method described under strictly standardized conditions. Any change in the performance will immediately influence the results.

\section{Quantitative Value of Diagrams of Urinary Proteins}

For the analysis of serum $0.02 \mathrm{ml}$. of material is used, equalling approximately $1.4 \mathrm{mg}$. of protein. The minimal amount of protein, with which a suitable diagram is obtained, appeared to be about $0.2 \mathrm{mg}$. Because not more than $0.04 \mathrm{ml}$. of material may be applied to a strip, the urines must contain at least $0.5 \%$ of protein in order to give any results.

The influence of the variation in the total amount of protein upon the quantitative values of the fractions was investigated. A series of dilutions was made from a serum sample, and from each dilution a diagram with the same quantity of fluid. The mutual ratio of the fractions was determined from the different diagrams. Tables II and III show the results. Within a variation of 1.4 to $0.6 \mathrm{mg}$.

TABLE II

ELECTROPHORESIS ON FILTER PAPER WITH VARIOUS AMOUNTS OF PROTEIN FROM ONE SERUM SAMPLE

\begin{tabular}{c|c|c|c|c}
\hline $\begin{array}{c}\text { Total } \\
\text { Protein } \\
\text { (mg.) }\end{array}$ & $\begin{array}{c}\text { Albumin } \\
\text { (\%) }\end{array}$ & $\begin{array}{c}\text { Alpha- } \\
\text { globulin } \\
(\%)\end{array}$ & $\begin{array}{c}\text { Beta- } \\
\text { globulin } \\
(\%)\end{array}$ & $\begin{array}{c}\text { Gamma- } \\
\text { globulin } \\
(\%)\end{array}$ \\
\hline $1 \cdot 5$ & 55 & 14 & 9 & 22 \\
$1 \cdot 5$ & 56 & 14 & 10 & 20 \\
$0 \cdot 75$ & 55 & 14 & 9 & 22 \\
$0 \cdot 6$ & 54 & 15 & 9 & 22 \\
0.4 & 51 & 16 & 9 & 24 \\
0.3 & 50 & 17 & 10 & 23 \\
$0 \cdot 2$ & 49 & 23 & 8 & 20 \\
0.15 & 41 & 21 & 8 & 30 \\
\hline
\end{tabular}

TABLE III

ELECTROPHORESIS ON FILTER PAPER WITH VARIOUS AMOUNTS OF PROTEIN FROM ONE SERUM SAMPLE

\begin{tabular}{c|c|c|c|c}
\hline $\begin{array}{c}\text { Total } \\
\text { Protein } \\
\text { (mg.) }\end{array}$ & $\begin{array}{c}\text { Albumin } \\
\text { (\%) }\end{array}$ & $\begin{array}{c}\text { Alpha- } \\
\text { globulin } \\
\text { (\%) }\end{array}$ & $\begin{array}{c}\text { Beta- } \\
\text { globulin } \\
(\%)\end{array}$ & $\begin{array}{c}\text { Gamma- } \\
\text { globulin } \\
(\%)\end{array}$ \\
\hline 1.4 & 55 & 8 & 7 & 30 \\
1.2 & 52 & 11 & 6 & 31 \\
0.9 & 52 & 11 & 6 & 31 \\
0.9 & 54 & 9 & 7 & 30 \\
0.8 & 54 & 10 & 7 & 29 \\
0.5 & 51 & 11 & 7 & 31 \\
0.3 & 47 & 15 & 9 & 29 \\
0.2 & 24 & 27 & 12 & 37 \\
\hline
\end{tabular}

of protein no real change is obtained. However, by using less than $0.6 \mathrm{mg}$. a decrease of the albumin percentage is observed and appears to be progressive. The following factors are responsible.
Paper Blank.-The paper blank of the various bands can be measured by determining the amount of dye on a corresponding protein-free area of the same strip. Under our working conditions this paper blank showed almost no variation. The paper blank of each fraction is directly related to its surface on the diagram. In relation to the globulin fractions the albumins take only a small part of the diagram. The paper blank, therefore, will result in a smaller increase of the total extinction of the albumin band in comparison with the globulins and so in a relative decrease of the albumin percentage. This decrease appears to be less than $1 \%$ in the case of serum analysis with $1.4 \mathrm{mg}$. protein. With decreasing amounts of proteins, however, the constant paper blank causes an increasing error.

Albumin Trail.-Merklen and Masseyeff (1952) pointed out that a part of the albumin is absorbed during its migration over the filter paper. In order to measure the quantitative value of this "albumin trail" certain diagrams were made with various amounts of pure albumin.

In spite of the great variation in the amount of albumin the extinction of all trails shows approximately the same value. The absorption appears to be independent of the amount of migrating albumin. Apparently the absorption is a saturation phenomenon.

The quantity absorbed differs, however, with the type of filter paper used, as was suggested by Merklen

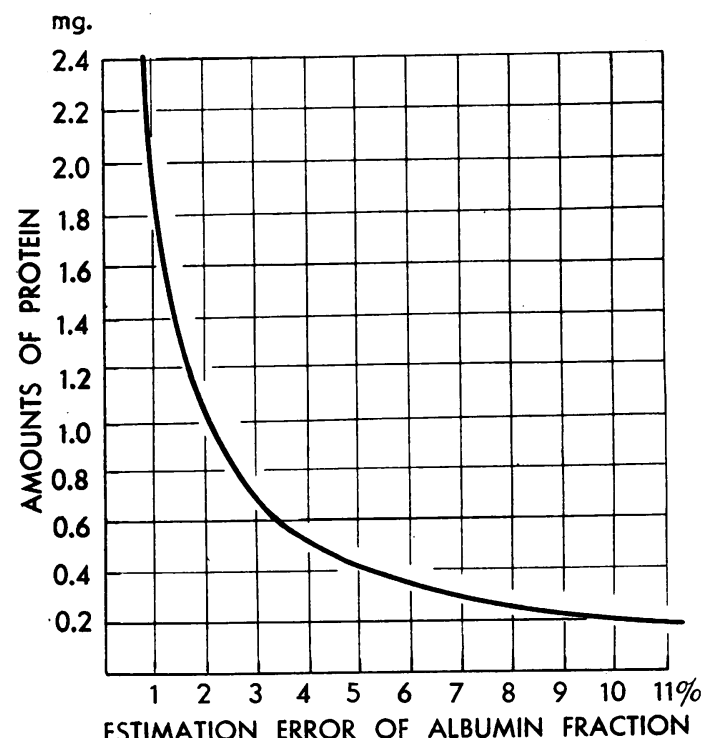

FIG. 4.-Relation between the amount of protein used for the analysis and the estimation error of the albumin fraction. 
and Masseyeff. For Whatman 1 filter paper we found the absorption to be $0.7 \mu \mathrm{g}$. of albumin $/ \mathrm{cm}^{2}$ Under the same working conditions, described above, this quantity appeared to be for Nagel and Mockery filter paper $0.5 \mu \mathrm{g}$. According to Slater and Kunkel the globulins show a trail as well. We, however, could not detect one after saturating the filter paper with albumin.

The albumin trail causes a decrease of the albumin percentage and an increase of the fractions running behind the albumins. By using a normal quantity of serum proteins $(0.02 \mathrm{ml}$.) this decrease appears to be about $1 \%$. With smaller amounts of proteins, this constant albumin trail will cause a further fall in the albumin percentage.

\section{Summary and Conclusions}

Both the paper blank and albumin trail are sources of errors always made when serum proteins are investigated by means of filter paper electrophoresis. Using a normal quantity of serum (about $1.4 \mathrm{mg}$. in $0.02 \mathrm{ml}$.) these errors cause under our working conditions a seeming fall of the albumin percentage of 1 to 2 .

With diminishing amounts of protein a further gradual fall in the albumin percentage will be observed. Fig. 4 shows the relation between the quantities of protein used for the analyses and the estimation error made for the albumin fraction. Within the range of 1.4 to $0.6 \mathrm{mg}$. the increase of the error remains just within one standard deviation of the albumin fraction, so only by using less than $0.6 \mathrm{mg}$. of protein will these errors result in an apparent fall of the albumin percentage.

Because not more than $0.04 \mathrm{ml}$. of material may be used for an analysis, the urines to be investigated must contain at least $1.5 \%$ of protein. With the method of concentration described, this protein content will easily be obtained in all cases of clinical proteinuria.

The minimal concentration of urines mentioned is only valid for the method described in this paper. By using another method, probably another value will be necessary. In any case the same kinds of errors will be made.

The method of filter paper electrophoresis of urinary proteins appeared to be simple and accurate, suitable for clinical purposes.

About 400 urines were investigated. The results will be published in another paper.

\section{REFERENCES}

Dole, V. P. (1944). J. clin. Invest., 23, 708.

Ewerbeck, H. (1950). Klin. Wschr., 28, 692.

Fauvert, R., and Hartmann, R. (1954). Les Albuminuries. Masson, Paris.

Merklen, F. P., and Masseyeff, R. (1952). C.R. Soc. Biol., Paris, $146,1905$.

Os, G. A. J. van (1952). Biochim. biophys. Acta, 9, 111.

Slater, R. J., and Kunkel, H. G. (1953). J. Lab. clin. Med., 41, 619.

Soulier, J. P. (1953). Presse méd., 61, 49.

Wael, J. de (1953). Chem. Weekbl., 49, 229. 